scribers informed of progress. Final reports, and most important publications of the texts found were included in the "Wissenschaftliche Veröffentlichungen". These undertakings were generously supported in Germany by such men as the late Dr. Simon, and foreign subscribers were numerous. For forty years the Deutsche Orient-Gesellschaft has held a leading place among societies of its kind, always insisting on a high standard of work in the field and the study not always attained by others. Sir Robert Mond was one of the foreign members who received the letter asking for his resignation and he informs us that he has answered, "that since your Council has unanimously decided to cease to be a scientific society, he no longer desires to be associated with it".

\section{Archæological Exploration in South-West Arabia}

IN another column of this issue of NATURE (see p. 140) a preliminary account is given by Miss G. Caton-Thompson of the geological and archæological results of the Lord Wakefield Expedition of Exploration in South-West Arabia, upon which she recently accompanied Miss E. W. Gardner, the geologist, and Miss Freya Stark, whose adventurous journeying in Arabia on a previous occasion will be fresh in the memory of readers. Miss Caton-Thompson, whose present record amplifies in detail the archæological and geological references of Miss Stark's account of the expedition in The Times of July 18-21, is far from being a novice in archæological exploration in conditions similar to those of her recent experience. With Miss Gardner as her geological colleague, she has investigated the evidences of early civilizations in the Faiyum and the Kharga oasis, while in Southern Rhodesia she has attacked, and, most archæologists would agree, has solved the problem of the Zimbabwe. In venturing with her colleagues into the rarely penetrated Hadhramaut she has initiated the archæological investigation of a problem, or group of problems, which has fascinated historian and geographer ever since the explorations in southern Arabia of Niebuhr in 1761-64 and of Halévy and Glaser more than a century later revealed in their collection of inscriptions the existence there of civilizations going back possibly so far as nearly a thousand years before Christ. Yet the archæological record has remained virtually blank, and although the great frankincense route from India to the eastern Mediterranean through southern Arabia traversed country known to the ancient world of Sumer, Akkad and ancient Egypt, it may be, in the third millennium B.C., nothing is known with certainty of the cultures and relations of those civilizations. Minaean, Sabaean, Himyaritic, and the like, which Miss Caton-Thompson, wisely, for the moment accepts collectively as pre-Islamic. The work of Miss Gardner and herself in the Hadhramaut has laid securely the foundations for the study of a group of problems which recent development in the pre. and protohistoric archæology of western Asia and Africa suggests may be one of the most important strategic points in future research.

\section{Excavations at Lachish, 1937-8}

THE interesting collection of antiquities from Tell Duweir, the ancient Lachish, in Palestine, on view at the Wellcome Research Institute, Euston Road, London, N.W.1, from July 7 until July 29 bears eloquent testimony to the organization of detail by the leader of the expedition, the late Mr. J. L. Starkey, which enabled the members of the WellcomeMarston Archæological Research Expedition to carry on without interruption after his murder on January 10 last. By that time the expedition had already arrived as near a solution as is likely to be possible of the problem of the great shaft, $80 \mathrm{ft}$. by $70 \mathrm{ft}$. by $80 \mathrm{ft}$. deep, at the south-east corner of the Tell upon which investigation was engaged at the close of last season. Tunnels driven along the sides at the bottom and up to the centre show that this great seventh century work was never completed, but that it was probably intended for a reservoir similar to that at Gezer. Excavation of the Bronze Age temple has now been completed down to bed rock, two pieces of evidence leading to redatings.

The early temple is now shown to be considerably earlier than was believed, a remarkable large polychrome pot with painted metopes, showing beautiful representations of ibex, ibis and tunny fish, being placed in a class of pottery dated by Mr.W.A.Heurtley at about 1550 B.o.; while a small faïence plaque of Amenhotep III was found in such a position as to place it beyond question that the building of the second temple falls within the reign of that monarch. Two Nineteenth Dynasty pottery sarcophagi, the first found at Lachish, in the form of 'slipper' coffins, have lids moulded to represent the features of the deceased, while a third bears an inscription in hieroglyph which is unique. It is by a scribe evidently unfamiliar with hieroglyphic writing, and although not yet fully interpreted, is in a formula which is not Egyptian. Early Bronze Age caves, dating at about 2500 B.c., showed evidence of occupation, as well as contracted burials. In one cave, of the Late Bronze Age, which in Judæan times had been used as a stable, was found a number of unfired pots which pointed to this having been a potter's workshop, while nearby in another cave was his stock.intrade. In a pit were pivoted stones which may have served as fly-wheels for the turn-table, while red and yellow ochre for painting, bowls for mixing the paints, pebbles and shells for polishing and burnishing, were part of the equipment. The interesting schoolboy scribing giving the order of the first four letters of the Judæo-Phenician script was found under the Jewish Palace steps the day the expedition ceased work.

\section{Archæological Research in Greece}

Among recent excavations and research in Greece recorded in the Annual of the British School of Archæology at Athens (35, Session 1934-35), first place in interest and importance is taken by the work of the School in Ithaca. Mr. W. A. Heurtley, who was in charge, describes the results of the excavation of 